\title{
THE SOURCES, GROWTH AND DEVELOPMENT OF THE LAW MARITIME.
}

I.

An acquaintance with the history of any branch of the law is always valuable to the lawyer. To the admiralty lawyer a knowledge of the sources of the Law Maritime is of the utmost importance. Its present condition being the outgrowth of more than three thousand years of commercial intercourse among the nations. engaged in the navigation of the seas, it is essential to a proper appreciation and understanding of its nature, scope and character at the present day that those who practice it should familiarize themselves with its history and be able to recall the various steps of its growth and progress.

It has been, and is, a just cause of complaint that of late years there has existed a perplexing conflict of decision among our admiralty courts upon several important questions. The criticism has been made that this conflict is in a measure to be attributed to the lack of familiarity on the part of some of our judges with the underlying principles of the law, which a knowledge of its older codes, rules and ordinances would have afforded. It is probably true that many of the unfortunate expressions to be found in our law reports would never have been employed if the persons (reporters, counsel and judges) who used them had been better acquainted with the law literature of the past.

But we have only to call to mind the examples of Lord Mansfield and Judge Story to illustrate the advantages which an admiralty lawyer who has explored the sources of the law possesses. The evident delight, not unmixed with reverence, with which those great expounders of the Lex Mercatoria and Law Maritime would, on occasion, turn to the fountains of the law is instructive and inspiring. In delivering judgment, with what satisfaction no doubt would Lord Mansfield, as in Luke vs. Lyde, 2 Burrows, 822, proceed to say: "I find by the ancientest laws in the world-the Rhodian laws, that the master shall have," etc. How much clearer was his insight into 
the case that was presented to him who could thus turn to a rule that had probably received the sanction of three thousand years of usage.

Indeed it is not going too far to say that to all lawyers the study of the admiralty law is not only profitable but necessary; for nothing is more certain than that its influence is felt in almost every department of the law. And it comes to us venerable with age, ennobled with an ancestry which no other branch of the law can be said to have possessed.

Let this then be my excuse for inviting the readers of the JourNAL to accompany me for a few moments in an examination of some of the circumstances which led to the creation of the law maritime, and of the leading events in its rise and development. I shall omit wherever it seems advisable reference to the authorities consulted and employed.

II.

To the Phoenicians, who were called Canaanites by the sacred writers, who inhabited the coast of the Mediterranean from the Island of Aerad to Mount Carmel, to which country they had been driven by the Hebrews, and whose chief city was Tyre, has been ascribed the distinction of being the inventors of a marine and the originators of maritime commerce. Their voyages were extended step by step from Sicily to Sardinia, Greece, Gaul, and Spain ; then boldly venturing beyond the Mediterranean and out upon the waters of the Atlantic their courage was rewarded by the discovery of Great Britain. For at least I600 years before the birth of Christ, Phoenicia had undisputed dominion over the sea and was the mistress and possessor of its commerce. Under the protection and with the assistance of the King of Egypt in the year 6rI B. C., Phoenician sailors set out upon the perilous undertaking of the circumnavigation of Africa; they were successful. But the power of Phoenicia was waning; she was losing her colonies one by one; and then the final catastrophe came. Nebuchadnezzar, King of Babylon, appeared before the walls of Tyre, and for thirteen years his armies thundered at her gates. Destroyed to her foundations; rebuilt under Cyrus; splendid under the reign of the Persian kings; again destroyed by Alexander the Great, re-established by his successors; passing successively under the empire of the Romans and of the Saracens; alternately prosperous and depressed, this first of the great commercial cities has passed away; and the prophecy of Ezekiel has been fulfilled: "They shall destroy the walls of Tyrus and break down her towers; I will also 
scrape her dust from her and make her like the top of a rock." But the Phoenicians had founded Carthage, and Carthage on the destruction of Tyre became the greatest power in the Mediterranean. Then came the three Punic wars, and this the then greatest commercial state measured its strength with no unequal success with the greatest military power; but finally in the year I46 B. C., Rome was victorious, and Carthage, a city of more than 20 miles in circumference and containing nearly a million inhabitants, was totally destroyed.

Following Phoenica the other great historic powers which claimed the empire of the sea were Rhodes, Persia, Greece, Macedonia, Carthage and Rome. And, then in their order, Pisa, Venice and Genoa. Pisa, on the suppression of the Roman Empire, had erected itself into a republic and soon became a formidable maritime power, and, maintaining numerous fleets, she with her powerful navy long enjoyed the distinction of being the mistress of the sea. But the repeated invasions of Italy by the Goths and Huns gave rise to a seat of trade on the waters of the Adriatic, and, from the islands of the sea there arose the marble walls of Venice, its famous exchange the Rialto, being the witness of transactions which reached farther and were of greater magnitude than the world had ever seen before. There it was that the first public bank of modern times was organized; that bills of exchange were first negotiated, and funded debt became transferrable; that finance became a science, and bookkeeping an art. And then came Genoa, following in the footsteps of Venice, her imitator, her rival and, finally, her enemy.

If it were advisable to refer more fully to the causes and the magnitude of the operations which created, nurtured and established the principles of the law maritime we should need to go no further than merely to mention the names of Portugal, Spain, Holland, France, England and the nations of northern Europe.

Were there any rules or laws of the sea by which the transactions of the merchants and mariners of ancient and mediæval Europe were governed, their rights protected and their obligations enforced; and, if there were, have they any connection with or bearing upon the laws of our modern commercial states? Assuming such a question to have been asked, let us attempt to answer it.

To Rhodes belongs the honor of promulgating the first authoritative code of maritime laws. Admirably situated, with excellent harbors and with a people having a natural genius for trade and love for the sea, Rhodes established a maritime empire more beneficient and more real than that of Phoenicia, and disdaining the con- 
quests of war, became the protector of the nations she might have enslaved-conferring benefits instead of creating discord, she presented to the world among the choicest of its gifts, a noble system of laws, which for a period commencing nine hundred years before the birth of Our Savior, and as yet without end, has compelled the admiration of jurists of every succeeding age and embellished the statute books of some of the most civilized and powerful of nations. They were the source of the maritime jurisprudence of Rome, and while they in their ancient form have probably not been handed down to us, with the exception perhaps of the fragment upon the law of Jettison which was incorporated into and became a part of the Roman Civil Law, we find that there are many other Rubrics of the Civil Law which relate to shipping that are not traceable to any earlier origin.

The law of General Average had its inception in the fragment upon the subject of jettison-De Jactu. Fourteen centuries after its promulgation in Rhodes, it was incorporated into the digest of Justinian, and for nearly three thousand years it has been a recognized law of commercial nations. It reads as follows: "It is provided by the Rhodian law that if goods are thrown overbcard in order to lighten a ship, the loss incurred for the sake of all shall be borne by the contribution of all." Here we have the substance of the whole doctrine of General Average Contribution as practiced among commercial men and adjusters of marine losses in every nation doing business upon the great maritime highways of the world. I venture to say that scarcely a week passes in the city of New York, or on the shores of the Great Lakes, in which this rule is not in some manner applied and enforced.

It is not known whether the Phoenicians, the Carthaginians or other ancient nations, their contemporaries, possessed or published any maritime laws or regulations. But we do find that when Rhodes, anxious and alarmed at the growing power of the insatiable Roman Republic, broke away from her connection with Macedonia and united her fortunes to those of the great republic, the Romans became acquainted with that comprehensive system of naval jurisprudence (the Rhodian laws) which they afterwards adopted. Rome had already become powerful upon the sea, and as a consequence had commenced the enactment of marine regulations-that is to say, an edict for the protection of the goods of persons travelling by sea had been issued. It is, however, in the gth title of the $4^{\text {th }}$ book of 
the Pandects that mention is made for the first time in the Roman law of ships and mariners. If space permitted, it would be profitable for us to enquire into, and examine, the system of maritime laws embodied in the Roman Digest. Indeed, we might go further than this with increasing interest and advantage, for the whole body of the civil law is full of instructive interest to the student, in view of the influence which it exercises upon the law merchant of the present day as administered by our courts of admiralty, as well in great measure by our courts of common law. And fortified by excellent authority, we might even venture the assertion that, in many instances where its regulations differ from those of the common law, the superiority of the civil law is readily perceived and appreciated.

Hence, we find that courts of admiralty in the broad exercise of their equitable powers, for they are peculiarly courts of equity, are largely governed by the rules of the civil law.

But there are other well cultivated fields to which those courts resort. We find them seeking rules for their guidance in the famous collection known as the Consolato Del Mare-the consulate of the sea-a voluminous compilation of laws relating to commerce and navigation, the origin of which is involved in some obscurity. It has been called "a collection of maritime and positive laws and of the particular ordinances of the middle and dark ages." (Hubner). Azuni, a native of Sardinia and a very accomplished writer, in his work on maritime law published in its different editions in the latter part of the I8th and early part of the I9th century, asserts that it appears to him that the Consolato can be the production of no other than the Pisans. And he supports his assertion with an interesting array of historical information and deductions. The Pisans certainly created a most complete and elaborate code of maritime laws, in many respects embodying and resembling the principles of those of the Rhodians and Romans; but if we are to be content with the statements of a learned writer upon the subject of the Consolato in the Encyclopaedia Britannica, the credit of its compilation and its embodiment in book form is due to Spain, and particularly to the city of Barcelona, where, late in the fifteenth century it was printed and appeared. Indeed the writer seems to concede the work to be purely of Spanish origin, both in conception and design. Facts are stated by him which can hardly be reconciled with the statement of Azuni, that the Consolato can be the production of no other than the Pisans. On the other hand, Azuni assures us that the Consolato was certainly compiled and universally known in the year I075 (four cen- 
turies prior to the Barcelona edition); that at that period the Barcelonians who have been credited with its authorship, assisted by the Pisans, had scarcely begun to shake off the yoke of the Saracens, and that they were shut off from the sea by the continual piracies and incursions of the Saracens. It is probable, however, that the Consolato was a gradual collection of the rules and usages among commercial nations from the 12 th to the 14 th century. We find it frequently referred to in connection with the subject of the ownership of ships, with the rights and duties of master and seamen, the law of affreightment, of equipment and supply, jettison, salvage, average, ransom and prize. Professor Parsons advises us that the best edition of the Consolato is that of Pardessus in his collection of maritime laws.

The citizens of Amalfi, a city founded in ancient Lucania by a colony of families fleeing from the tyranny of Rome at the close of the ninth century, it is said, created a system of maritime laws that even eclipsed the laws of Rhodes. They were called the Amalfian Table; but as no vestige of them has come down to us the fact of their existence possesses scarcely more than a mere historic interest.

We come now to the laws of Oleron, so often quoted and cited in the opinions of judges and by text writers, and which are to-day to be found in every well furnished law library. They were published on the island of Oleron, an island situated two leagues distant from the coast of France, near Rochelle. Perhaps the best and most authentic account of their creation is that which ascribed them to Queen Eleanor, then Duchess of Guienne. Eleanor, having observed the high reputation which the Consolato had acquired throughont the Levant, on her return from the Holy Land immediately caused a compilation to be made of the maritime sentences and judgments of the West, under the title of "Role d'Oleron." These laws were published about the year II5O, and relate to the navigation and sale of a ship, the duties of the master and mariners, wreck, freight, salvage, jettison, injuries to cargo, quarrels on board ship, collisions, supplies, stranding, etc., but do not mention the important subject of marine insurance.

Another celebrated body of laws to which reference is often made by the courts and by counsel are those which were compiled by the merchants and burgesses of Wisbuy. Wisbuy was an important city situated upon the island of Gottland in the Baltic sea, belonging to Sweden, and was in its day the most flourishing mart and fair in Europe. 
In the introduction to the laws of Wisbuy in I Peter's Admiralty Decisions, we find this interesting sketch of that once opulent city:

"In the northwest part of the island, Wisbuy was situated, a fair and noble seaport; it was built by foreigners, whose first settlement in the country was opposed by the Gottlanders, but who successfully resisted them, and in the year one thousand two hundred and eightyeight obtained an important victory over them, after which the citizens to defend themselves against their enemies, obtained a permission from Magnus, king of Sweden, to wall their city and erect bastions and other fortifications. They flourished more and more and grew great by their trade and navigation, to which they entirely gave themselves up; there being no city so full of merchants and so famous for its commerce. Hither came Swedes, Russians, Danes, Prussians, Livonians, Germans, Finlanders, Vandals, Flemings, Saxons, English, Scots, and French to trade. Each nation had its quarter and particular streets for its shops or warehouses. All strangers were safe and welcome there, and enjoyed the same privileges as the townsmen themselves. The magistrates of the city had the jurisdiction or rather the arbitrament of all causes or suits relating to sea affairs. Their ordinances were submitted to in all such cases, and passed for just on all the coasts of Europe, from Muscovy to the Mediterranean. In the course of time this town was entirely destroyed, except the citadel, which stands to this day. The Gothic historians do not tell us when or how its destruction came upon it, only that it was through civil dissensions which arose from trifles, but occasioned great factions, which set them so against one another that it ended in the entire ruin of them all, city and citizens. The ruins of it are now to be seen and under them are often found tables of marble, porphyry and jasper, evidences of the ancient splendor and magnificence of the citizens. The houses are covered with copper, the windows gilt with gold, and all that is said or that is discovered of it shows the inestimable riches of the former inhabitants. The citizens who survived the ruin of the city retired to the country of the Vandals and Eastern Saxons, who were enriched with their wealth. Albert, king of Sweden, rebuilt the city and granted great privileges to all that should come and inhabit it; but it never could recover its trade and former magnificence."

The laws of Wisbuy appeared some time in the Iath century, and were largely founded upon the laws of Oleron and the commercial usages of Lubeck and Amsterdam. They were adopted by all the nations of the North, and furnished what must have been regarded 
as a very complete and satisfactory guide to them in their commercial relations and transactions. They are particularly interesting, from the fact that they contained what is believed to be the first allusion to the law of marine and life insurance.

Passing over the naval laws of the ancient city of Marseilles with the single remark: that published in the ${ }^{3} 3^{\text {th }}$ century they contain many chapters on navigation and maritime contracts, we come next in order of time to the important naval ordinances of the Hanseatic towns. The confederation of Hanseatic cities originated at Bremen in 1164 ; it included 62 European cities, without reckoning other towns which afterwards joined the league. This league was purely a commercial partnership by which those cities which were members of it divided the profits of the trade carried on by the association. This co-partnership, the history of which is full of interest, survived until the year 1669 , when the last general assembly was held. Henceforth the name "Hanse-town" was kept by Lubeck, Hamburg and Bremen, but it was to designate their independence, not their union. The marine ordinances of this league were published for the first time at Lubeck in I59I. They were corrected and enlarged in I614, and as thus completed consisted of fifteen chapters subdivided into a great number of articles.

For a long period the kingdom of France possessed no maritime laws, except those contained in the compilation known as "Le Guidon." Le Guidon probably originated in the year I400; it relates mainly to Bottomry and Insurance and is frequently cited.

We might appropriately close our historical notice with an examination of the celebrated Marine Ordinance of Louis XIV. This code of laws has been called a "most masterly act of legislation

* * * the common law of all the neighboring nations." $\mathrm{Mr}$. Abbott observes that, "in matter, method and style it is one of the most finished acts of legislation that ever was promulgated." Lord Mansfield acknowledged that he had derived much of his knowledge of maritime law from it and from the elaborate commentary of Valin upon it. The ordinance was published in I68r. The names of its authors are unknown. But, whoever its authors were, they certainly displayed in its preparation the most consummate learning and ability. It covers, says Professor Parsons, "the whole ground of maritime law $* * *$ enacting with clearness and perspicuity all the provisions then in force, whether derived from $* * *$ general tradition, from previous enactments, or from usage."

We have now glanced at the principle sources of the admiralty 
law as administered by the courts of this country and England. Neither possesses a complete system of statutory regulations upon this branch of jurisprudence, and yet as has been aptly remarked by Mr. Flanders "the maritime jurisprudence of England is grounded on the Law Merchant, which is a branch of the law of nations and forms a part of the English common law; and upon the rules and usages which prevail among commercial men of all countries. Her courts of admiralty, like those of the United States, proceed according to the civil law, the laws of Oleron and other generally received collections of maritime law; the customs of admiralty and particular statutes."

"It is not enough," said the SupremeCourt in the case of the Lottawanna, 2I Wall. 558, "to read the French, German, Italian and other foreign works on the subject, or the codes which they have framed, but we must have regard to our own legal history, constitution, legislation, usages and adjudications as well. The decisions of the Supreme Court *** are especially to be considered." Therefore, while as a general proposition, it is true that in the codes and compilations above mentioned are to be found the substructure of the existing maritime law of the commercial world, this statement if left by itself might be somewhat misleading so far as it relates to England and America.

For those compilations possess no binding or arbitrary force upon our courts; they are in some instances modified or disregarded by the courts of both countries, or as the Supreme Court also said in the case of the Lottawanna "the maritime law is operative in any country only so far as it is adopted by the laws and usages of that country." Neither is it true that England and the United States possess no statutory or authoritative regulations upon this branch of jurisprudence. On the contrary, Magna Charta itself contained a provision for the security of foreign merchants trading in England. While in this country we have, first, the constitutional provision which gives to our federal courts jurisdiction of all admiralty and maritime causes; second, numerous acts of Congress for the regulation of commerce and shipping, notably the laws for the registry and inspection of vessels, their clearance from and entry at the ports of the United States; relating to the transportation of passengers and merchandise; for the suppression of piracy; a very complete merchant seaman act for the protection of sailors; a body of prize laws; rules of navigation designed to prevent collisions, etc. Third, the decisions, of the courts, which in their local application and because 
of the peculiar and varying conditions of our commerce have in numerous instances departed from the rules established by the law makers of the old world.

Thus far, our inquiries have been confined for the most part to laws of a statutory or arbitrary character. What shall be said of the array of elementary treatises and commentaries that have resulted from the labors, that are the product of the genius and learning of the distinguished body of text writers who have sought and with great success, to enrich, amplify and expound this branch of the law. For nearly 250 years the local literature of Europe has been immeasurably illumined as from time to time their works have appeared. No other branch of the law has been discussed and commented upon with greater fullness and ability. I think that I should understate the number if I were to say that there were 50 of these treatises. The titles of some of these works and a brief description of their character are given by Professor Parsons, beginning at page I2 of vol. I of his work on shipping and admiralty. But the list there given is far from complete.

The interested student of the law could not better employ some of his leisure time than in glancing at the list and description of the works upon admiralty law set forth in the opening chapter of Jacobsen's Sea Laws, itself a work of the greatest merit and erudition.

Placed at the head of the catalogue of English writers we find the name of Molloy, his work De Jure Maritimo et Navali, is often quoted and is much admired.

To the American lawyer, the decisions of the Supreme Court of the United States are the final authority upon questions of admiralty law arising in causes prosecuted in our national courts. When that court decides a proposition, the question which it involves is settled. It will not avail that the courts of England, the text writers, the codes of continental Europe or the decisions of our inferior courts, appear to differ from it-the investigation is ended. The law is declared when that court has rendered its decision. The pages of the reports of the Supreme Court are rich in adjudications upon this important branch of the law, and they furnish those who pursue it the finishing, and at the same time a most instructive, chapter in the history of the growth and development of the admiralty law.

George S. Potter. 